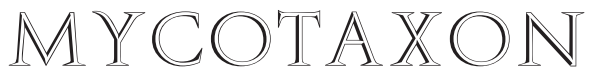

Volume 111, pp. 323-330

January-March 2010

\title{
New taxa in the genus Lyophyllum s.l. from La Palma (Canary Islands, Spain)
}

\author{
Rose Marie Dëhncke ${ }^{1}$, Marco Contu ${ }^{2}$, Alfredo Vizzini ${ }^{3 *}$ \\ *alfredo.vizzini@unito.it \\ ${ }^{1}$ Finca 'Los Castañeros' \\ 38710 Breña Alta - La Palma (Islas Canarias), España \\ ${ }^{2}$ Via Marmilla, 12 (I Gioielli 2), I-07026 Olbia (OT), Italy \\ ${ }^{3}$ Dipartimento di Biologia Vegetale - Università degli Studi di Torino \\ Viale Mattioli 25, I-10125, Torino, Italy
}

\begin{abstract}
Four new taxa in the genus Lyophyllum (L. brunneum, L. infidum, L. pseudoloricatum, and L. pseudoloricatum f. lactellum), collected in La Palma (Canary Islands), are here described and taxonomically delimited based on morphological data. For each species detailed descriptions, microscopical drawings and plates are presented. Notes on closely related species are also added.
\end{abstract}

Key words - Basidiomycota, Agaricomycetes, Lyophyllaceae, taxonomy, biodiversity

\section{Introduction}

Among the numerous collections of Lyophyllaceae made in La Palma (Canary Islands) during a long-term survey of Agaricales, several interesting taxa were found, some of which were well characterised both macro- and micromorphologically and deserving of special attention and a formal description.

The present paper deals with four of them, all belonging to Lyophyllum P. Karst. emend. Kühner, viz., L. brunneum sp. nov., L. infidum sp. nov. and L. pseudoloricatum sp. nov., the last one being collected also in a white form, which is also proposed as new. All the agarics presented in this paper were collected in mixed forests with Pinus radiata D. Don and/or Pinus canariensis C. Sm., at an altitude of 1300-1400 m a.s.l.

\section{Materials and methods}

The macromorphological descriptions follow the detailed field notes taken for each collection on fresh material by the first author. The micromorphological descriptions are 
based both upon study of fresh and herbarium material. Dried material was revived in $\mathrm{KOH} 2 \%$ and stained in Congo red and Phloxine B. Cotton Blue was utilized to highlight the siderophilous granulation in the basidia (Baroni 1981). Spore measurements are based on means of 30 spores. The width of basidia was measured at the thickest part, and the length was measured from the apex (sterigmata excluded) to the basal septum. We followed the taxonomic concept of Bon (1999) for the Lyophyllaceae because a natural (molecular based) classification has not yet been proposed for this group, despite the important preliminary study by Hofstetter et al. (2002). Abbreviations of author names follow Kirk \& Ansell (2003). Colour notations in the macroscopic descriptions are from Séguy, Code Universel des Couleurs (1936), cited here as (Se). Herbarium abbreviations are according to Holmgren \& Holmgren (1998). All examined material (type-collections included) is housed at TO (Herbarium generale del Dipartimento di Biologia Vegetale, Università degli Studi di Torino, Italy). Latin descriptions of all new taxa are deposited in MycoBank (http://www.mycobank.org).

\section{Taxonomy}

Lyophyllum brunneum Dähncke, Contu \& Vizzini, sp. nov.

FIGs. 1a, 2a-c

MycoBAnk MB515106

Pileus 3-7.5 cm latus, carnosus, convexus, brunneus, radialiter fibrillosus. Lamellae subconfertae, subliberae, cremeae deinde roseo-brunneae. Stipes 6-9 $\times 1.5-2.5 \mathrm{~cm}$, solidus, clavatus et haud bulbosus, albus, politus. Caro firma, alba, immutabilis. Odor saporque debiles. Sporae 6-7(-7.5) × 4.5-5(-5.5) $\mu \mathrm{m}$, late ellipsoideae vel ellipsoideae, obtusae, leves. Basidia 30--38 × 7-9 $\mu \mathrm{m}$, tetraspora. Cellulae marginales 20-45 × 3.5-5 $\mu \mathrm{m}$, diverticulatae vel nodulosae, abundantes. Pilei cutis ex hyphis iacentibus, radialibus, 2-7 $\mu \mathrm{m}$ latis efformata. Fibulae numerosae.

Holotypus: Hispania, Insulae Canariae, in insula La Palma dicta, ad locum dictum El Pilar, 25.XI.2007, leg. R.M. Dähncke (TO HG1725).

Етумоlogy. The specific epithet, derived from the Latin adjective brunneus, - $a,-u m$, refers to the brown-pigmented pileus.

Pileus 3-7.5 cm wide, fleshy, broadly convex or convex-paraboloid with an inrolled margin, not expanding, without umbo, dry, glabrous even if radially fibrillose, fuscous-brown (Se 131-134) then brown (Se 691-692) with a darker center (Se 126), not or scarcely hygrophanous. LAMELLAE close, horizontal, almost free, moderately thin to thin, at first cream (Se 199, 200) then pinkish to pinkish-brown (Se 202-204), brownish $(691,703)$ in old basidiomata, not staining when bruised. STIPE $6-9 \times 1.5-2.5 \mathrm{~cm}$, solid, clavate, often with an inflated basis, lacking a bulb, polished, white, stuffed with a thick white pith. CONTEXT thick in the disk but progressively thinner towards the pileus margin, white, unchanging; smell and taste none.

Spores $6-7(-7.5) \times 4.5-5(-5.5) \mu \mathrm{m}$, on average $6.8 \times 4.7 \mu \mathrm{m}$, hyaline, cyanophilous, carminophilous, broadly ellipsoid to ellipsoid, smooth, with a single, central, oil-drop, apex obtuse. BAsIDIA 30-38 × 7-9 $\mu \mathrm{m}$, four-spored, clavate, with basal clamp-connection; suвнyмenium ramose, made up of 

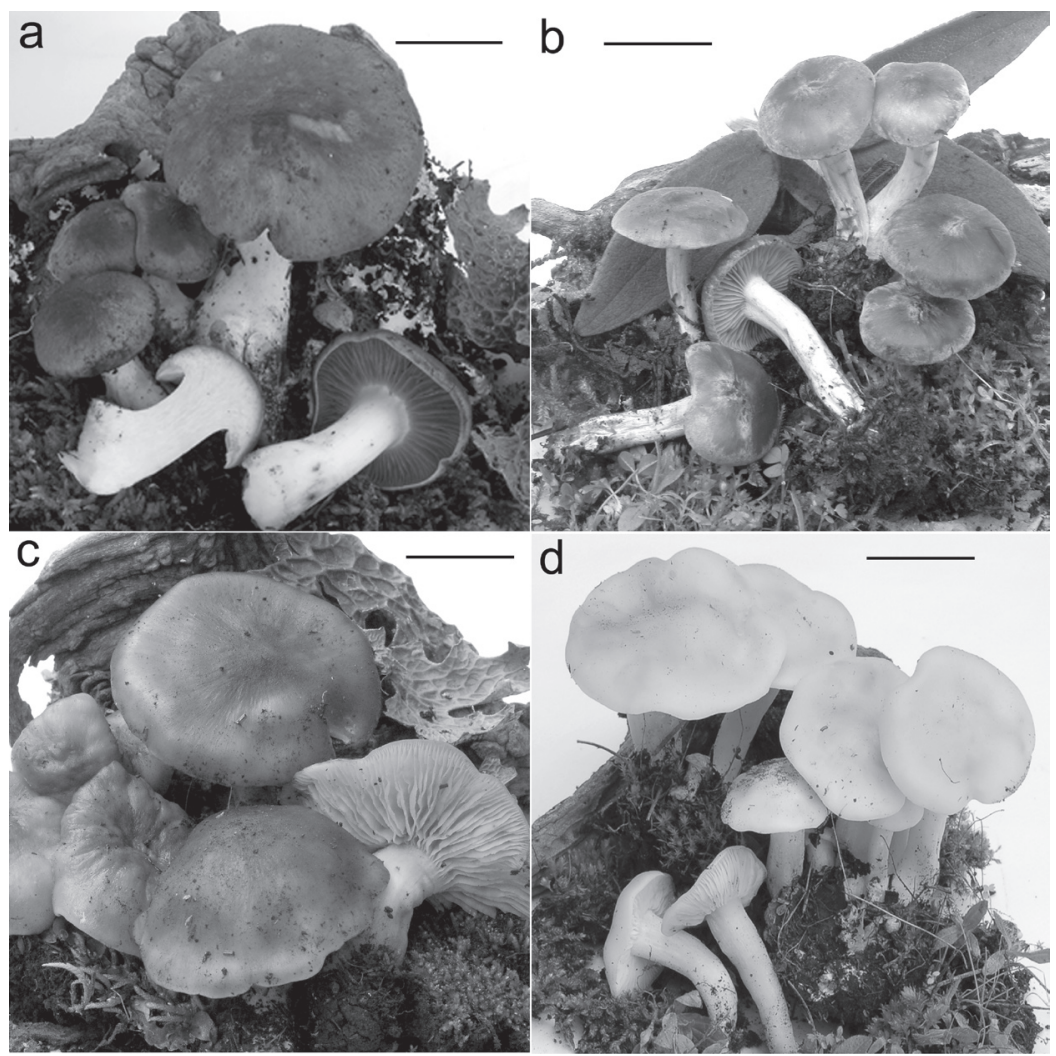

Figure 1. Basidiomes. a. Lyophyllum brunneum. b. L. infidum. c. L. pseudoloricatum. d. L. pseudoloricatum f. lactellum. Scale bars $=2 \mathrm{~cm}$

thin hyphae. Hymenophoral trama regular, made up of thin, hyaline hyphae. Marginal cells 20-45 × 3.5-5 $\mu \mathrm{m}$, abundant, diverticulatenodulose, thin-walled, hyaline, sometimes uni- to pluriseptate. PILEIPELlis a compact xerocutis of repent, smooth, cylindro-clavate hyphae, 2-7 $\mu$ m wide, with dominant parietal pigment which is also vacuolar in some elements. Stipitipellis a cutis of elongate hyphae. Clamp-CONneCtions present at all septa. Thromboplerous hyphaE not seen.

Habitat. Caespitose in mixed woods with Pinus canariensis and Pinus radiata. Autumn.

Comments. Lyophyllum brunneum is unique in the section Aggregata due to the fleshy stature, the brown tinges in the pileus, the abundant nodulose marginal cells, and broadly ellipsoid spores. Lyophyllum subglobisporum Consiglio \& Contu 2001, also collected by the first author in La Palma, differs 
in having smaller, less elongate spores and in lacking marginal cells (Consiglio \& Contu 2002); L. pseudoloricatum (see below) has a cartilaginous context, bigger spores, cellular subhymenium, and lacks marginal cells. The European key to Lyophyllum section Aggregata (Bon 1999) cites some French records of an unpublished entity close to L. loricatum (Fr.) Kühner ex Kalamees 1994 but showing "cheilocystides important mais variables, de lagéniform à +/- lobéesdiverticulées." Globose spores and a more hygrophanous pileus differentiate this fungus from L. brunneum.

Lyophyllum infidum Dähncke, Contu \& Vizzini, sp. nov.

FIGs. 1b, 2d-e

MycoBank MB515107

Pileus 2-2.5 cm latus, parce carnosus, convexus, ad medium umbonatus, pallide griseobrunneus, pruina alba obtecto. Lamellae subconfertae, adnatae, griseo-brunneae. Stipes 3-4 $\times$ 0.3-0.6 cm, fragilis, cylindricus, pileo pallidior, fibrillosus. Caro parce conspicua, brunnea, in siccis nigrescens. Odor saporque farinacei. Sporae 5.2-6.7 × 3-4.5 $\mu \mathrm{m}$, late ellipsoideae vel ellipsoideae, obtusae, leves. Basidia 25-30 $\times 7-8 \mu \mathrm{m}$, tetraspora. Cellulae marginales nullae vel incospicuae. Pilei cutis ex hyphis iacentibus, radialibus, 2-7 $4 \mathrm{~m}$ lat. efformata. Fibulae numerosae.

Holotypus: Hispania, Insulae Canariae, in insula La Palma dicta, ad locum dictum Hoyo del Rehielo, 19.XI.2005, leg. R.M. Dähncke (TO HG1726).

ЕтумоLоgy. The specific epithet is derived from the Latin adjective infidus, $-a,-u m$ (= not faithful) and therefore meaning a deceptive, not obvious, species.

Pileus 2-2.5 cm wide, not very fleshy, subcartilaginous, broadly convex or convex-paraboloid, then convex but never expanding, with a small and rounded central umbo, dry, white-pruinose, light greyish-brown (Se 427) with a darker center (Se 434), hygrophanous and fading with age. LAmELlaE close, adnate, moderately thin to thin, greyish-brown (Se 233-235), not staining when bruised but black in dried material. STIPE $3-4 \times 0.3-0.6 \mathrm{~cm}$, not solid, subequal, paler than pileus, surface appressed fibrillose. ConTEXT thin, brownish, apparently unchanging but black in dried material; smell and taste farinaceous.

SpOREs 5.2-6.7 × 3-4.5 $\mu \mathrm{m}$, on average $5.8 \times 3.7 \mu \mathrm{m}$, hyaline, cyanophilous, carminophilous, broadly ellipsoid to ellipsoid with an obtuse apex, smooth, with several oil-drops, very slightly thick-walled. BAsIdiA 25-30 $\times 7-8 \mu \mathrm{m}$, four-spored, clavate, with basal clamp-connection; sUBнyмENIUM made up of inflated, hyaline elements. Hymenophoral trama regular, made up of thin, hyaline hyphae. Marginal cells inconspicuous. Pileipellis a compact undifferentiated cutis of repent, smooth, cylindrical hyphae, 2-7 $\mu \mathrm{m}$ wide, with dominant parietal pigment; SUPRAPELLIS not or very scarcely gelatinized. Stipitipellis a cutis of elongate hyphae. Clamp-Connections present at all septa. Thromboplerous hyphaE not seen.

HaвiтAт. Under Cistus symphytifolius Lam. near some trees of Pinus canariensis, in small groups. Autumn. 


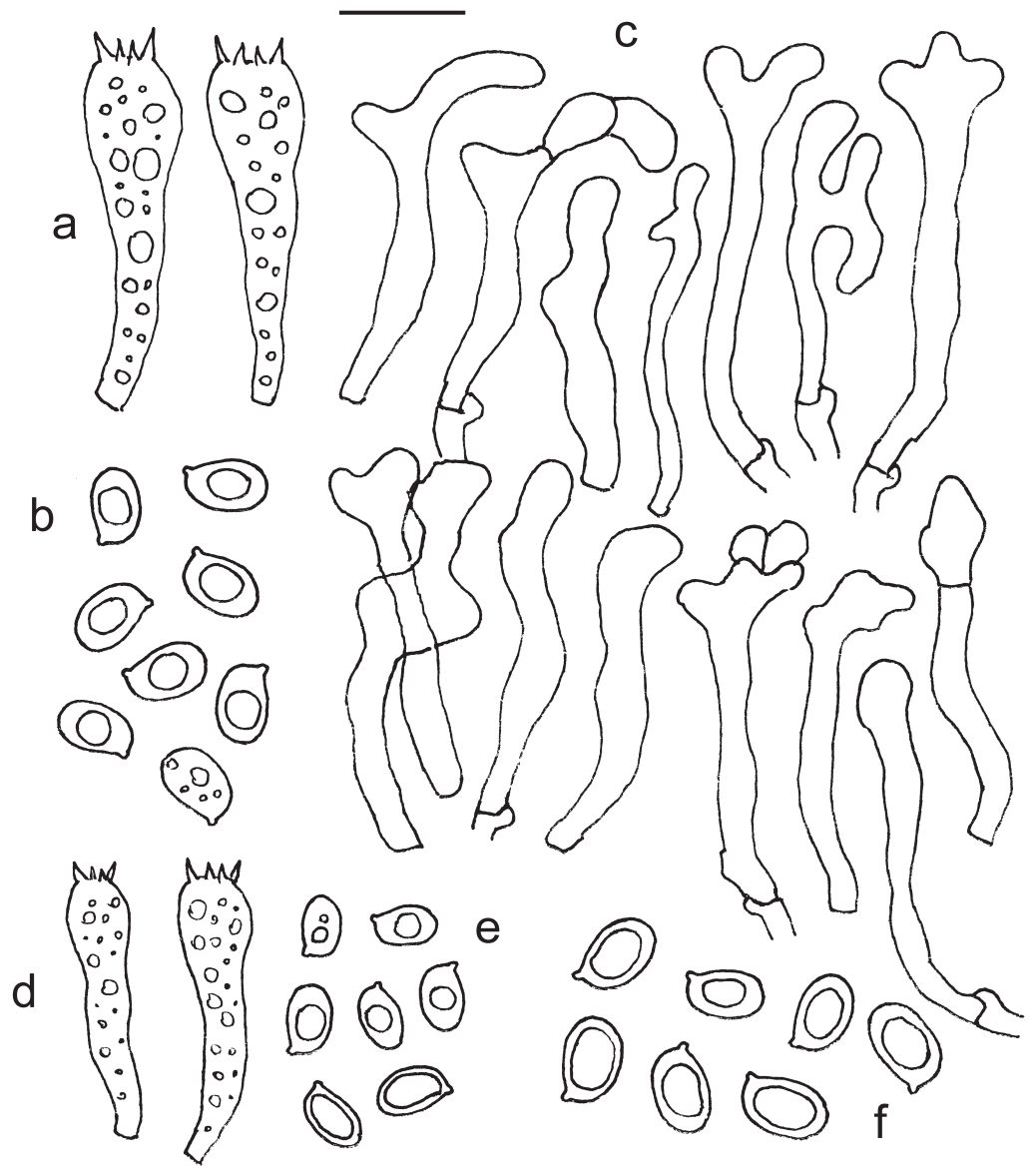

Figure 2. Basidiomes. Microscopical features.

Lyophyllum brunneum (from the holotypus). a. Basidia. b. Spores. c. Cheilocystidia.

L. infidum (from the holotypus). d. Basidia. e. Spores.

L. pseudoloricatum (from the holotypus). f. Spores.

Scale bar $=10 \mu \mathrm{m}$

Comments. Lyophyllum infidum is well characterized by the pale greyishbrown tinges and central umbo of the pileus, the nearly unchanging surface when handled, the farinaceous smell and taste, and, micromorphologically, by the small, ellipsoid spores. Lyophyllum bonii Contu 1996 (Consiglio \& Contu 2002) has a similarly tinged pileus, but it lacks an umbo, has decurrent lamellae, and larger, less elongate spores. At first we thought that our collection was an ecoform of L. semitale var. intermedium Romagn. 1987 (Romagnesi 1987, Bon 1999, Consiglio \& Contu 2002), a variety repeatedly collected by the first author 
in La Palma (material revised by M. Contu), but this has bigger spores with an ogival apex and a clear suprahilar depression, a different (non-farinaceous) smell and taste, and larger basidia (Clémençon 1986, Kalamees 2004). Lyophyllum brunneo-ochrascens E. Ludw. 2001, also characterized by a brown to fuscousbrown, pruinose pileus surface and farinaceous smell and taste, differs in having much larger spores, viz. "7-9.5 × 4.5-6 $\mu \mathrm{m}$ " in the protologue (Ludwig 2001) whilst L. pulvis-horrei E. Ludw. \& Koeck 2001 (Ludwig 2001), another smallsized species, is easily distinguished by its non-pruinose umbonate pileus, more adnate to decurrent lamellae, different smell, and narrower, subglobose to broadly ellipsoid spores. Moreover, L. pulvis-horrei grows caespitose in open grasslands (Ludwig 2001).

Finally, L. ignobile (P. Karst.) Clémençon 1982 is an additional European species with small to medium-sized basidiomes and ellipsoid spores, but it is distinguished by usually darker tinges, more elongate and narrower spores, and a different (non-farinaceous) smell and taste (Clémençon 1982, 1986). Among the extra-European species cited by Clémençon \& Smith (1983), we should mention L. fuligineum (Peck) Singer 1942, which Peck described as possessing a fuscous pileus, grey stipe, and blackening context with farinaceous smell and taste (Saccardo 1891). Lyophyllum fuligineum, however, clearly differs from L. infidum by the fleshy context, darker, non-umbonate pileus, stouter (thicker) stipe, and larger, more elongate spores (Singer 1942; Clémençon 1982-typestudy of Tricholoma fuligineum Peck 1888).

Lyophyllum pseudoloricatum Dähncke, Contu \& Vizzini, sp. nov.

FIGS. 1c, 2f

MycoBank MB515108

Pileus 3-7.5 cm latus, carnosus, cartilagineus, convexus, brunneus, rugulosus. Lamellae parce confertae, uncinato-adnatae, cremeae. Stipes $4-5 \times 1.5-2 \mathrm{~cm}$, solidus, clavatus ed haud bulbosus, albus, politus. Caro firma, alba, immutabilis. Odor saporque debiles. Sporae 6-8(-8.4) × 4.5-6 $\mu \mathrm{m}$, late ellipsoideae vel ellipsoideae, obtusae, leves. Basidia 30$40 \times 8-10 \mu \mathrm{m}$, tetraspora. Cellulae marginales nullae vel incospicuae. Pilei cutis ex hyphis iacentibus, radialibus, 2-5 $\mu$ m latis efformata. Fibulae numerosae.

Holotypus: Hispania, Insulae Canariae, in insula La Palma dicta, ad locum dictum Pajonales, 23.XI.2007, leg. R.M. Dähncke (TO HG1727).

Eтymology. The specific epithet refers to the resemblance of this species to the morphologically closely related $L$. loricatum.

Pileus 4-7 cm wide, fleshy, elastic-cartilaginous, broadly convex with an inrolled margin in young stages, expanding, without umbo, dry, glabrous, rugulose, brown (Se 691-693) with a darker center (Se 707, 711), hygrophanous and distinctly fading with age. LAmellae not very close to subdistant, uncinate-adnate, moderately thick to thick, cream, not staining when bruised. STIPE 6-7 × 1.5-2 cm, solid, clavate, often with an inflate base, lacking a bulb, polished, white, stuffed with a thick white pith. CONTEXT thick in the disk but 
progressively thinner towards the pileus margin, white, unchanging; smell and taste none.

Spores $6-8(-8.4) \times 4.5-6 \mu \mathrm{m}$, on average $7.6 \times 5.4 \mu \mathrm{m}$, hyaline, cyanophilous, carminophilous, broadly ellipsoid to ellipsoid, smooth, with a single, central oil-drop, apex obtuse. BASIDIA 30-40 × 8-10 $\mu \mathrm{m}$, four-spored, clavate, with basal clamp-connection; sUBHYMENIUM made up of inflated elements. HYMENOPHORAL TRAMA regular, consisting of hyaline hyphae. MARgInAL CELLS 20-40 × 2-4.5 $\mu \mathrm{m}$, rare, not well-differentiated, not peculiar, cylindricoflexuose, hyaline, thin-walled. Pileipellis a xerocutis of differentiate, repent, smooth, cylindrico-clavate hyphae, 2-5 $\mu \mathrm{m}$ wide, with dominant parietal pigment, SUPRAPELLIS an ixocutis of very thin elements; SUBPELLIS and PILEI TRAMA with progressively wider hyphae. STIPITIPELLIS a cutis of elongate hyphae intermixed with abundant thromboplerous hyphae. Clamp-Connections present at all septa. Thromboplerous hyphaE abundant.

Habitat. Caespitose in mixed woods with Pinus canariensis or P. radiata. Autumn.

Additional material studied: Spain, Canary Islands, La Palma, Hoyo del Rehielo, 23.XI.2007, leg. R.M. Dähncke (TO HG1728); - ditto, in the very same habitat, 25.X.2008, leg. R.M. Dähncke (TO HG1729); - ditto, Pared Vieja, in a pine wood with Pinus radiata, 25.X.2008, R.M. Dähncke (TO HG1730).

Comments. In general appearance, L. pseudoloricatum greatly resembles L. loricatum, which also shares the same cartilaginous context. The two species are, however, readily distinguished by the spore shape: broadly ellipsoid in our new species in contrast to globose in L. loricatum as well as in most species in section Aggregata. To our knowledge, the sole species of this section having non-globose spores is L. subglobisporum (Consiglio \& Contu 2002), which was also collected by the first author in La Palma (material revised by M. Contu); L. subglobisporum, however, is readily distinguished by the broader spores, smaller and less elongate basidia, and non-cartilaginous context. Among the extra-European species we have not been able to find anything similar.

Lyophyllum pseudoloricatum f. lactellum Dähncke, Contu \& Vizzini, f. nov.

MycoBank MB515109

FIG. 1D

A typo solum differt basidiocarpo albo-lacteo.

Holotypus: Hispania, Insulae Canariae, in insula La Palma dicta, ad locum dictum Hoyo del Rehielo, 15.XII.2006, leg. R.M. Dähncke (TO HG1731).

Етумоцоgy. The epithet refers to the milky-coloured pileus.

Comments. Apart from the white colour, this agaric is fully identical to L. pseudoloricatum; therefore, we think that it should be regarded as a white form of the latter. This record is very interesting because until now white forms of usually coloured species were not known in Lyophyllum s.l. 


\section{Acknowledgements}

We are very grateful to Prof. E. Grilli (Popoli, Italy) for the critical and linguistic revision of the manuscript. Our most sincere thanks are due to Prof. I. Krisai-Greilhuber (Department of Systematic and Evolutionary Botany, University of Vienna, Vienna, Austria) and to Prof. H. Clémençon (Faculty of Biology and Medicine, University of Lausanne, Lausanne, Switzerland) for their pre-submission reviews.

\section{Literature cited}

Baroni TJ. 1981. The genus Rhodocybe Maire (Agaricales). Beihefte zur Nova Hedwigia 67: 1-194.

Bon M. 1999. Flore Mycologique d'Europe. Les Collybio-marasmioïdes et ressemblants. Doc Mycol Mémoire hors-série n. 5. Amiens. 171 pp.

Clémençon H. 1982. Types studies and typifications in Lyophyllum (Agaricales). I. Staining species. Mycotaxon 15: 67-94.

Clémençon H. 1986. Schwärzende Lyophyllum-Arten Europas. Zeitschr für Mykol 52 (1): 61-84.

Clémençon H, Smith AH. 1983. New species of Lyophyllum (Agaricales) from North America and a key to the known staining species. Mycotaxon 17: 379-437.

Consiglio G, Contu M. 2002. Il genere Lyophyllum P. Karst. emend. Kühner, in Italia. Riv Micol 45(2): 99-181.

Hofstetter V, Clémençon H, Vilgalys R, Moncalvo J-M. 2002. Phylogenetic analyses of the Lyophylleae (Agaricales, Basidiomycota) based on nuclear and mitochondrial rDNA sequences. Mycol Res 106: 104-1059.

Holmgren PK, Holmgren NH. 1998. (continuously updated). Index Herbariorum: A global directory of public herbaria and associated staff. New York Botanical Garden's Virtual Herbarium. http:// sweetgum.nybg.org/ih/ (accessed 19 July 2009).

Kalamees K. 2004. Palearctic Lyophyllaceae (Tricholomataceae) in Northern and Eastern Europe and Asia. Scripta Mycol 18: 3-134.

Kirk PM, Ansell ME. 2003. Authors of Fungal Names. Index of Fungi Supplement. CAB International, Oxon, UK (electronic version).

Ludwig E. 2001. Pilzkompendium, Bd.1 Beschreibungen: Die kleineren Gattungen der Makromyzeten mit lamelligem Hymenophor aus den Ordnungen Agaricales, Boletales und Polyporales. Eching.

Romagnesi H. 1987. Sur la tribu des Lyophylleae Kühner (Agaricales, Tricholomaceae). Beitr Kenn Pilz Mittel III: 17-123.

Saccardo PA. 1891. Sylloge Fungorum omnium hucusque cognitorum. IX. Supplementum universale. 1. Agaricaceae-Laboulbeniaceae. Patavii.

Séguy E. 1936. Code Universel des Couleurs. Paul Chevalier, ed. Paris. 68 p. 48 pl.

Singer R. 1942. Type studies on agarics. Lloydia 5: 97-135. 